\title{
Design and Economic Analysis of Grid- Connected Photovoltaic on Electrical Engineering Building in Universitas Andalas
}

\author{
Syafii $^{\# 1}$, Zaini ${ }^{\# 2}$, Dona Juliandri ${ }^{\# 3}$ Wati $^{* 4}$ \\ \#Electrical Engineering Department, Faculty of Engineering, Universitas Andalas, Padang, Indonesia \\ ${ }^{1}$ syafii@eng.unand.ac.id \\ 2zaini@eng.unand.ac.id \\ 3 juliandri.tan@gmail.com \\ *Accounting Education Department, STKIP PGRI Sumatera Barat, Padang, Indonesia \\ 4tegowati73@gmail.com
}

\begin{abstract}
This paper proposes a design and economic analysis of grid-connected photovoltaic power system on the roof of Electrical Engineering building in Universitas Andalas. The system is designed based on a real measurement data of small scale $1.25 \mathrm{kWp}$ PV system on the rooftop Electrical Engineering Department and upscale to reach system designed. The PV system design result shows that the peak load of Electrical Engineering Department can be shaved from $29.5 \mathrm{~kW}$ to be $15.9 \mathrm{~kW}$ by install 104 solar panels or $26 \mathrm{kWp}$ PV system. The initial investment required to build the PV system is IDR 445 million. The economic feasibility study has considered weather conditions from BMKG data per year and discount rate $4.25 \%$. The result of economic analysis suggests that the development of PV system on the Electrical Engineering building based on MV tariff is feasible for all feasibility criteria. However, for social tariff was used the cost of PV energy per kWh higher than PLN tariff IDR 735 per $k W h$. This value indicate that the project is not profitable. Therefore, the installation of on grid PV system for university building need to considered the recent electrical tariff regulation.
\end{abstract}

Keyword - PV System design, economic analysis, NPV method and peak load reduction

\section{INTRODUCTION}

Indonesia is one of the countries that pass through the equator and have tropical climate so that the potential of solar energy in Indonesia is quite high. The potential of Indonesia's natural resources is very large, especially from solar energy if it can be exploited properly. The average daily solar energy potency reaches $4.8 \mathrm{kWh} / \mathrm{m}^{2}$ because sunlight is available almost from morning till late afternoon [1]. However, the solar energy which has been utilized only about 71.02 MWp both grid and off-grid connected [2]. The reduction and elimination of electricity subsidies and the enactment of incentives for renewable energy use led to an increase in the development and construction of photovoltaic on roofs of houses and buildings [3]. In addition to being environmental friendly, the construction of photovoltaics at the load center can reduce network losses, reduce land investment costs and reduce dependence on fossil energy, thereby enhancing energy sustainability and independence.

Universitas Andalas as one of national University in West Sumatera will build its own power plant based on renewable energy power generation toward be one of energy-independent campus in Indonesia. The electric power consumed by Universitas Andalas Buildings is around $1500 \mathrm{~kW}$ which has been supplied by National Electricity Company (PLN) grid. Universitas Andalas must paid not less than IDR 700 million per month for electrical energy. Electrical Engineering Department as one of building in the Universitas Andalas have concrete floor space on buildings rooftop potentially to install solar power plant. However, to obtain accurate solar energy expediency analysis, it is necessary to study the feasibility of technology and finance of rooftop PV system installation.

Several studies of designing photovoltaic (PV) systems on the rooftop of university buildings have been done [4-6]. The analysis in ref [4] revealed that the Engineering Faculty at Mu'tah University consumed 96 MWh annually and by installing an on-grid photovoltaic system with a capacity of $56.7 \mathrm{~kW}$. The electricity production from solar inject to the grid will be $97.02 \mathrm{MWh}$ per year, which could cover the electricity demand for Engineering Faculty at Mu'tah University with a capital cost of $\$ 117,000$ and payback period about 5.5 years. The hybrid system supply design on the rooftop of Udayana University has been presntented in [5]. Another comprehensive study of design and economic feasibility study of campus-wide photovoltaic systems in New England was reported in [6]. The design result justified that PV system have a potential and feasible to build on the university building, however the weather condition and actual performance need to consider and improve. 
In general, previous research above at the design and economic analysis stage have used assumption data so that it will likely different treatment when installed on a particular area. In this research, the analysis of on grid system based on PV system from actual small scale pilot project [7] and real data of weather condition from Meteorological, Climatological, and Geophysical Agency (BMKG) to get important parameters in the designing and economic analysis of rooftop PV system installation. The PV system is designed to reduce the peak load of the Electrical Engineering Department at Universitas Andalas in West Sumatera and an economic approach is applied to calculate the feasibility for the design.

\section{PV SySTEM DESIGN}

In The PV system to be designed on the Electrical Engineering Building in this study is a grid connected PV system. Grid connected PV systems have many technical advantages such as flexibility, simplicity to install in areas where solar irradiation is available, because it is non-polluting, does not require batteries for storage. Therefore, many countries encourage their customers to install PV systems and generate their own power. Furthermore, the installation of PV system can reduce utility bills and increase the contribution of renewable energy to limit carbon dioxide $\left(\mathrm{CO}_{2}\right)$ emissions. The grid-connected system consists of PV panels and inverters. The inverter converts the direct current (DC) power generated by the PV arrangement into an alternating current (AC) current synchronized with the mains power utility or PLN. Excess electricity generated at any time is fed into the grid.

The potential of solar energy located on the Electrical Engineering, Universitas Andalas can be accessed through the NASA's data portal [8]. By input the latitude coordinates and longitude coordinates of the Electrical Engineering Department, Universitas Andalas, in Padang, West Sumatera, the potential of solar energy can be seen in Table I is $4.91 \mathrm{kWh} / \mathrm{m}^{2} / \mathrm{d}$ in average.

TABLE I. The potential of Solar Energy in Universitas Andalas

\begin{tabular}{l|c|c|c}
\hline \multicolumn{1}{c|}{ Month } & Clearnees index & Temperature $\left({ }^{\circ} \mathrm{C}\right)$ & Solar radiation $\left(\mathrm{kWh} / \mathrm{m}^{2} / \mathrm{d}\right)$ \\
\hline \hline January & 0.478 & 24.9 & 4.85 \\
February & 0.501 & 25.1 & 5.23 \\
March & 0.409 & 25.2 & 5.15 \\
April & 0.505 & 25.4 & 5.13 \\
May & 0.525 & 25.6 & 5.03 \\
June & 0.540 & 25.5 & 4.97 \\
July & 0.521 & 25.2 & 4.87 \\
August & 0.492 & 25.3 & 4.85 \\
September & 0.472 & 25.1 & 4.87 \\
October & 0.469 & 25.1 & 4.88 \\
November & 0.445 & 25.0 & 4.53 \\
December & 0.457 & 24.9 & 4.58 \\
\hline \hline
\end{tabular}

The first step in the design of solar power systems is the determination of the daily load demand of Electrical Engineering buildings to be saved by PV system. Since the purpose of design is to reduce peak load of power consumption during the day or working hour, it is necessary to calculate the amount of electricity consumption that exceeds the average load or minimum load power. The formula used in calculating power consumption is based on the composite trapezium rule using the following equation:

$$
E_{c}=\frac{h}{2}\left(P_{0}+2 \sum_{i=1}^{n-1} P_{i}+P_{n}\right)
$$

where:

$$
\begin{array}{ll}
\text { Ec } & =\text { energy consumtion (kWh) } \\
\mathrm{h} & =\text { time interval (hour) } \\
\mathrm{n} & =\text { number of power data }
\end{array}
$$

The photovoltaic power capacity in kWp can be calculated by using equation [5]:

$$
P_{P v}=\frac{E C}{H_{\text {sun }}} \frac{1}{\eta_{\text {system }}}
$$


where:

$P_{p v} \quad=$ Photovoltaic system power capacity $(\mathrm{kWp})$

$H_{\text {sun }} \quad$ = sun hour per day (hour)

$\eta_{\text {System }}=$ System efficiency (\%)

The IPV250P solar panel is used which maximum power in STC 250 Watt, 31.2 Volt polycrystalline silicon type as PV module specification Table II.

TABLE II. PV module specification

\begin{tabular}{c|c}
\hline Description & Specification \\
\hline Power module (Wp) & 250 \\
\hline VMP (V) & 31.2 \\
\hline IMP (A) & 8.02 \\
\hline Voc (V) & 37.9 \\
\hline Isc (A) & 8.45 \\
\hline Size (L x W x H) m & $1650 \times 992 \times 40$ \\
\hline Weight of module $(\mathrm{kg})$ & 20 \\
\hline
\end{tabular}

The energy produced by PV system have been evaluated in previous research [7] as show in Table III below:

TABLE III. Energy generated under difference weather condition

\begin{tabular}{l|c|c}
\hline Weather condition & Average Power (Wp) & Energy (kWh)/day \\
\hline Clear Sky & 559.07 & 6.709 \\
\hline Cloudy & 451.36 & 5.416 \\
\hline Overcast & 302.15 & 3.623 \\
\hline Raining & 127.53 & 1.530 \\
\hline
\end{tabular}

Under design stage the clear sky weather condition is chosen, therefore the energy consumed 6,709 $\mathrm{kWh}$ per day is used as Ec. The sun hour and efficiency system can be obtained from equation (2):

$$
H_{\text {sun }} \eta_{\text {system }}=\frac{E c}{P_{P_{v}}}=\frac{6.709}{1.25}=5.367
$$

Therefore, the equation (2) can be reduce to be:

$$
P_{P v}=\frac{E C}{5.367}
$$

The number of PV panel $\left(N_{P V}\right)$ can be calculated using:

$$
N_{P V}=\frac{P_{P V}}{P_{\text {panel }}}
$$

The number of series connected panels $\left(N_{\text {series }}\right)$ can be calculated by the following equation:

$$
N_{\text {series }}=\frac{V_{D C}}{V_{M P}}
$$

The number of panels connected in parallel ( $\left.N_{\text {parallel }}\right)$ can be calculated by the following equation:

$$
N_{\text {parallel }}=\frac{I_{D C}}{I_{M P}}
$$

While DC current $\left(\mathrm{I}_{\mathrm{DC}}\right)$ :

$$
I_{D C}=\frac{P_{P V}}{V_{D C}}
$$

Then area of PV array can be calculated using:

$$
\text { Area of array }\left(\mathrm{m}^{2}\right)=N_{\text {series }} * L * N_{\text {parallel }} * H
$$


An inverter is used in the system to meet the need for AC power output. For grid connected systems, the inverter must be large enough to handle the total amount of wattage needed at one time. The inverter is chosen based on the selected PV panels because its function is just changing so that the inverter power is approaching power from solar panels, it is intended to get the maximum efficient of the inverter. However, the inverter selection must obey the conditions that deal with issues of power quality and MPPT [9].

\section{PV System Economic ANALysis PARAMETERS}

The economical calculation of the PV system in Electrical Engineering buildings uses a business feasibility study calculation system to determine investment criteria. These criteria can be used to determine the profitability of a project. The most common criteria used to examine the profitability of a project are net present value (NPV), payback period, cost of energy and internal rate of return (IRR).

Net present value (NPV) is applied in capital budgeting to analyze the profitability of an investment or project and this formula is sensitive to the reliability of future cash inflows that an investment or project will yield. NPV compares the value of money received today and the value of that same amount of money in the future by taking inflation and rate of return into account. NPV is based on discounted cash flow (DCF) techniques with three basic steps. The first step is to find the present value of each cash flow, including all inflows, outflows, and discounted at the project's cost of capital.

NPV is the ratio between the value of the market investment and the cost itself. If the NPV value is negative, then the project is not recommended to be implemented, if the value is positive, then the project is feasible to implement. NPV value is zero means there is no difference if the project is still implemented or rejected. The formula for determining NPV is as follows [10].

$$
N P V=\sum_{t=0}^{m} \frac{C I F_{t}}{(1+k)^{t}}-\text { Invest }
$$

Payback period is a period of time required to recoup the fund expended in an PV investment or to reach the break-even point. The calculation of payback period is done to know the financial risk of the project be done. The smaller payback period will be better, with the risk factor for return on capital will be faster in a short time. In calculating the payback period is usually called the payback method by dividing the initial capital issued with income received by investors for a year. The use of payback period in calculating the effectiveness of investment still has limits. The payback period does not calculate the profit earned after the payback period and has limitations in comparing the two projects.

Cost of energy (COE) is the ratio of the total annual cost of the system over the energy it produces during the same period. The COE calculation of the PV system is determined by Life Cycle Cost (LCC), Cost Recovery Factor (CRF), and the amount of energy generated. CRF is a factor used to convert all cash flow from life cycle cost into a series of payments or annual fees of the same amount. CRF calculations is as follows.

$$
C R F=\frac{B i(1+i)^{m}}{(1+B i)^{m}-1}
$$

by using the value of CRF, cost of energy can be calculated by using the following way.

$$
C O E=\frac{L C C \times C R F}{k W h}
$$

The annual maintenance and operational costs for PV system, generally accounted for $1-2 \%$ of the total initial investment cost [11]. The large percentage of annual maintenance and operational expenses for the PV power plant covering costs for solar panel cleaning work, maintenance and inspection costs of equipment and installations will be set at $1 \%$ of the initial total investment because Indonesia only have two seasons i.e. the rainy season and the dry season so that the cost of cleaning and maintaining the solar panel is not as large as the country that have four seasons in one year. In addition, the determination of this percentage is also based on the level of wage labor in Indonesia which is cheaper than the wage rate of labor in other countries.

\section{RESUlT AND Discussion}

Electrical energy that will be supplied by PV system is electrical energy obtained from power consumed above the minimum daily load demand. The power consumption of the Electrical Engineering Department changes every time following the daily load curve as shown in Fig 1, while the minimum power is $10.6 \mathrm{~kW}$. By using equations (1) and considered the minimum power, The electrical energy that will be served by solar power can be calculated as below: 


$$
E_{c}=\frac{1}{2}\left(P_{0}+2 \sum_{i=1}^{10}\left(P_{i}-10.6\right)+P_{11}\right)=131.8 k W h
$$

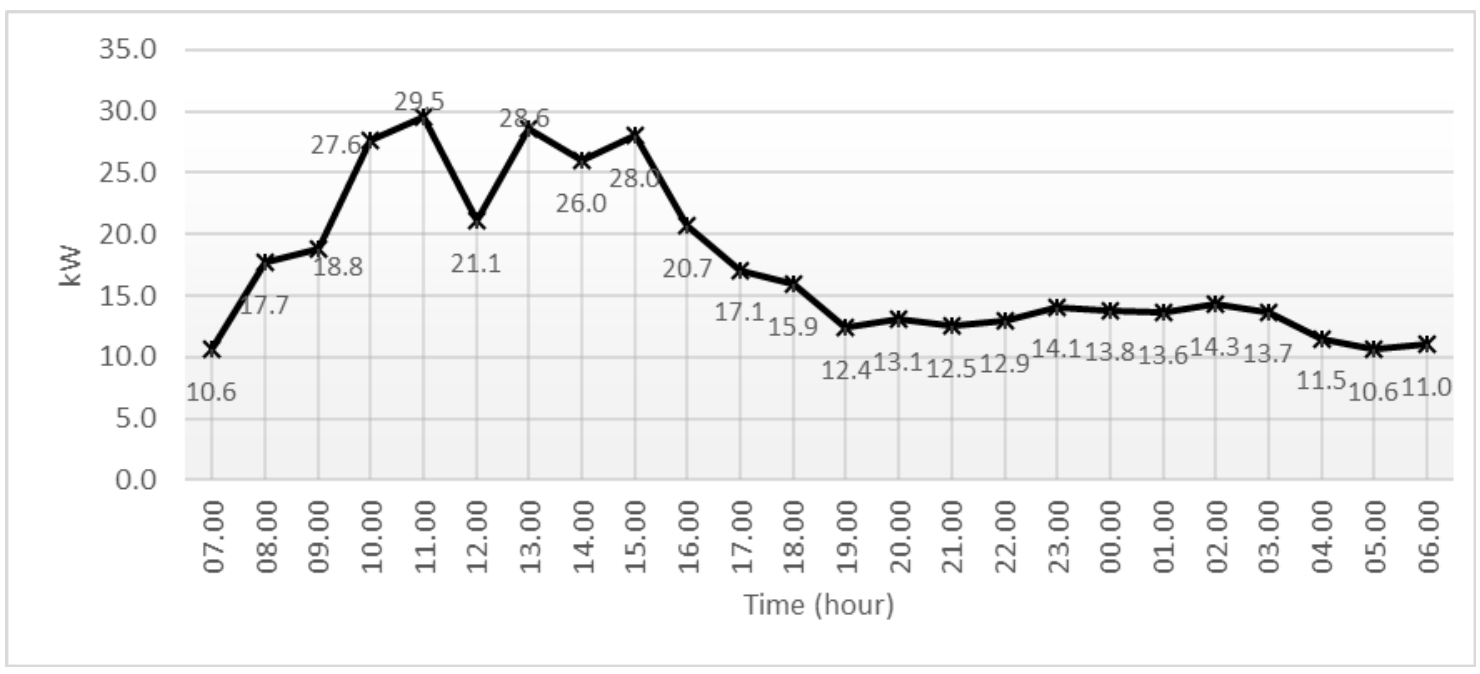

Fig.1 Daily load curve of Electrical Engineering Department

The photovoltaic power capacity of Electrical Engineering building calculated by using equation (3) is 24.5 $\mathrm{kWp}$, number of panel can be calculated using equation (4) for the capacity of each panel $0.25 \mathrm{kWp}$. The DC voltage system design is $400 \mathrm{~V}$ and $\mathrm{V}_{\mathrm{MP}}$ obtained from datasheet of PV panel is 31.2 Volt, therefore number of panels in series connection is $400 / 31.2=13$. The DC current system design is $24.5 / 400=61.37 \mathrm{~A}$ and $\mathrm{I}_{\mathrm{MP}}$ obtained from datasheet of PV panel is $8.02 \mathrm{~A}$, therefore number of panels in parallel connection can be calculated based on load current over the $\mathrm{I}_{\mathrm{MP}}(8.02 \mathrm{~A}$ ) obtained from datasheet of PV panel is 61.37/8.02 $=7.65$ $\cong 8$. The last step of PV designed in this study is to calculate the area needed on the rooftop of Electrical Engineering Department using equation (8). Thus the summary of the initial design and realistic design can be seen in Tabel IV.

TABLE IV. PV system design of Electerical Engineering Building

\begin{tabular}{|r|l|c|c|}
\hline No & \multicolumn{1}{|c|}{ Design description } & Initial Design & Realistic Design \\
\hline 1 & PV system size $(\mathrm{kWp})$ & 24.55 & 26 \\
\hline 2 & Number of Modules & 98 & 104 \\
\hline & Series & 12.82 & 13 \\
\hline & Parallel & 7.65 & 8 \\
\hline 3 & Area of array $\left(\mathrm{m}^{2}\right)$ & 160.58 & 170.23 \\
\hline
\end{tabular}

The total load curve of the Electrical Engineering Department buildings before and after shaved are shown in Fig. 2. The result in Fig 2 shows that the peak load of Electrical Engineering Department can be reduced from $29.5 \mathrm{~kW}$ to be $15.9 \mathrm{~kW}$ by installed $26 \mathrm{kWp}$ PV system which amounts of PV panels 104 units. The total area $170.23 \mathrm{~m}^{2}$ needed for PV system installation on the roof of Electrical Engineering building. 


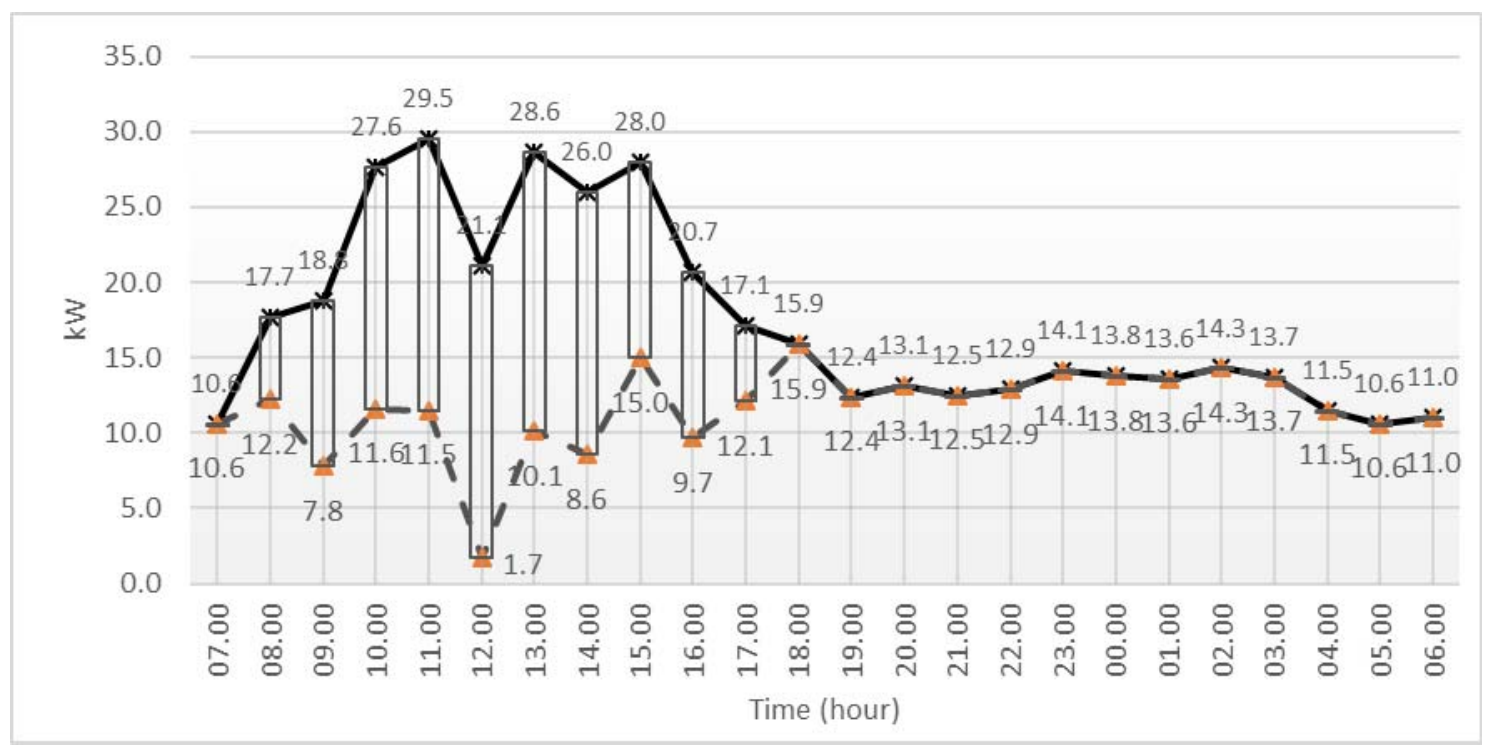

Fig. 2. PV installation reduce EF peak load

\subsection{Economic Feasibility}

The investment period is limited by the estimated lifespan of the PV system components is 25 years. Included in the initial investment cost of the PV system is the cost for purchasing PV system components such as solar panels, grid-tie inverters, MCB, wires and relays. Where price information of solar panel and grid-tied inverter can be obtained from ICA Solar price list. The initial investment cost estimation used in this study is IDR 445,500,000 as show in Table V.

TABLE V. Cost estimate of PV system installation

\begin{tabular}{c|c|c|c|c}
\hline Component Description & Type/Size & Quantity & Unit Price (IDR) & Total (IDR) \\
\hline PV module & 250Wp Poly & 104 & $12,500 / \mathrm{Wp}$ & $425,000,000$ \\
\hline Grid-Tied PV Inverter, 3P & SNV-GT-1502/30 kW & 1 & $80,000,000$ & $80,000,000$ \\
\hline \multicolumn{4}{c|}{ Installation MCB, Cables, busbar and fuses (10 \% of PV system cost) } & $40,500,000$ \\
\hline \multicolumn{4}{c|}{ Total cost } & $445,500,000$ \\
\hline
\end{tabular}

The amount of electrical energy that can be generated by the 104 units of solar panels for a year is calculated based on actual small-scale PV data for various weather conditions Table II with upscaling factor 19.64. The weather condition data for Padang city obtained from Meteorological, Climatological, and Geophysical Agency (BMKG). Based on the BMKG data the average weather condition can be summarized in percentage per year as show in Table VI. By using this data, the potential of energy of PV system designed can be generated 32,652.54 $\mathrm{kWh} /$ year.

TABLE VI. PV system energy generated per day

\begin{tabular}{c|c|c|c}
\hline Weather condition & Energy $(\mathrm{kWh}) /$ day [7] & Percentage per year & Energy $(\mathrm{kWh}) /$ year \\
\hline Clear Sky & 6.709 & $15 \%$ & $7,214.12$ \\
\hline Cloudy & 5.416 & $39 \%$ & $15,141.80$ \\
\hline Overcast & 3.623 & $35 \%$ & $9,090.14$ \\
\hline Raining & 1.53 & $11 \%$ & $1,206.48$ \\
\hline \multicolumn{3}{c|}{ Average energy generated } \\
\hline
\end{tabular}




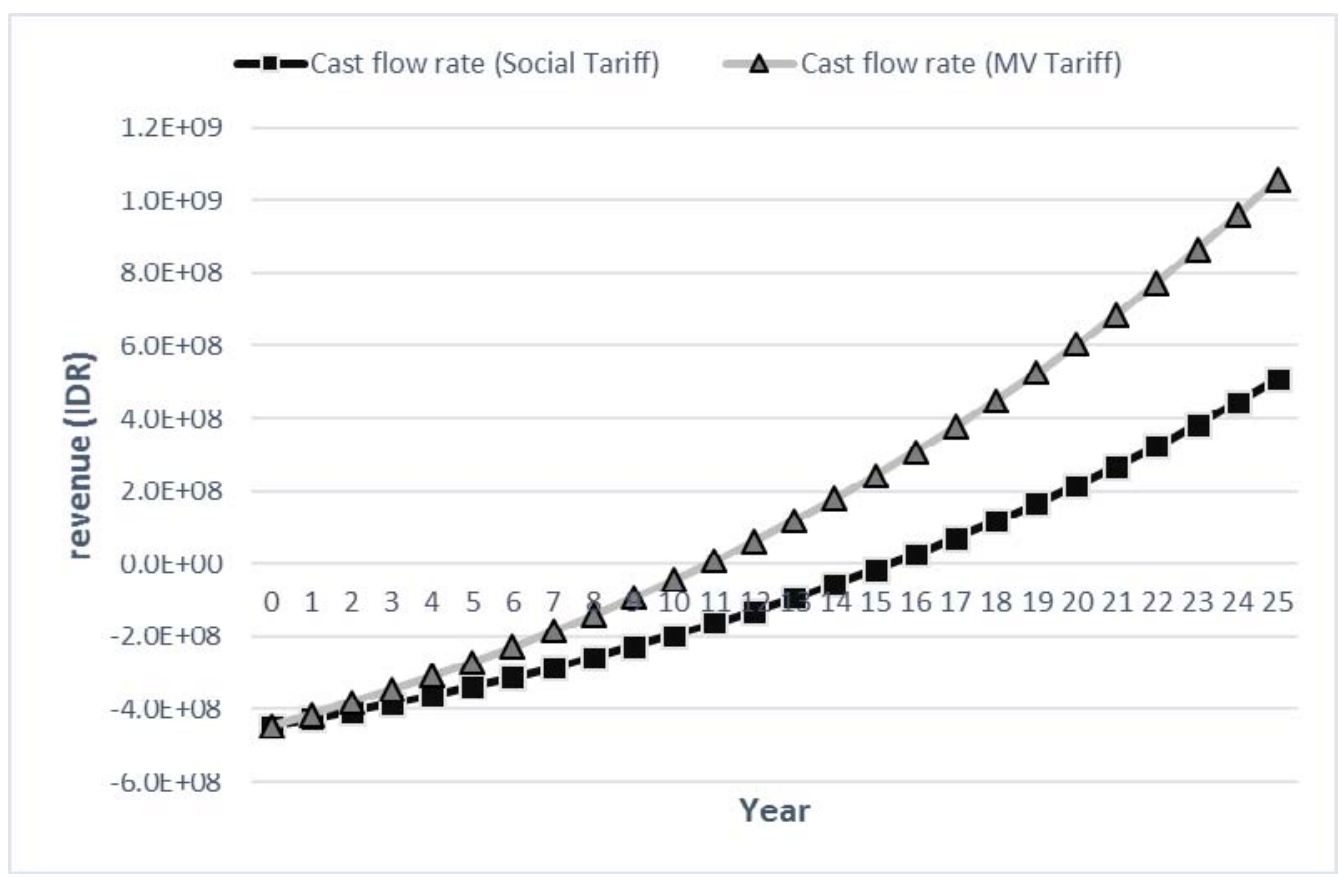

Fig. 3. Simple payback period

In the economic analysis the electricity tariff assumption used is IDR 1114.74 per kWh based on electricity tariff for medium voltage (MV) load connected to $20 \mathrm{kV}$ by PLN 2018 [12] and also compared with social tariff IDR 735. The estimated annual module degradation $0.5 \%$, rate of tariff increase $5 \%$ and the life expectancy of the solar panels were assumed to be 25 years as determined by the most of solar companies [6]. The interest rate using of Bank Indonesia (BI) rate for 2018 i.e. 4.25\% [13]. Fixed maintenance and operational costs are 1\%.

The simple payback period can be calculated by dividing total PV system investment cost by yearly savings. The result of simple payback period from cash flow rate calculation is shown in Fig 3 for both MV tariff and social tariff used. The simple payback period as shown in Fig. 3 is 10 years for MV tariff and 15 years for social tariff. However, the discounted payback period can be determined from Fig. 4 show that for MV tariff 13 years and for social tariff 20 years.

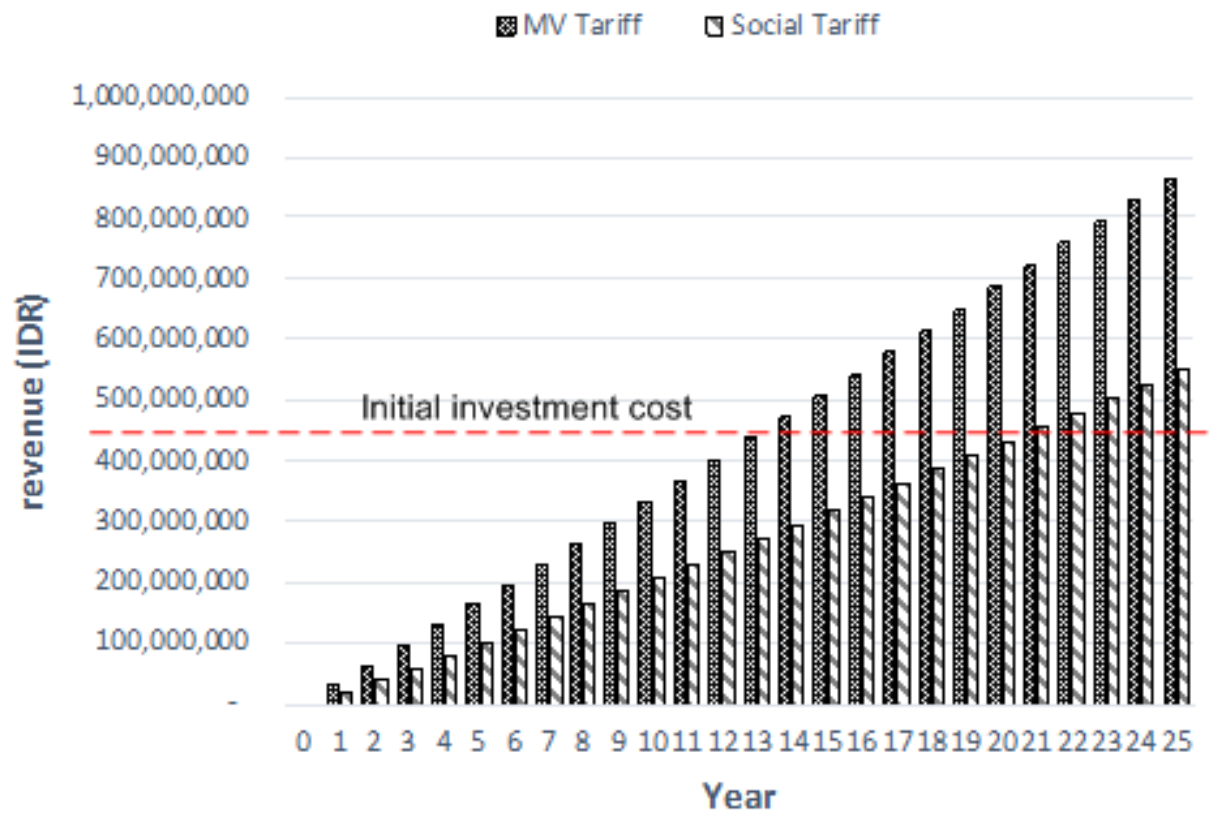

Fig. 4. Present value cumulative Net Cash flow (NCF) 
Net present value compares the value of an investment today to the future value of the money based on inflation and returns. NPV is a simple calculation of difference between the present value of cash inflows and outflows using equation (9). A positive value of NPV indicates a favorable investment. The simple method for calculating the cost of energy is the ratio of total investment plus the O\&M cost over the total energy produced over project period. However, the cost of $\mathrm{kWh}$ produced based on net present value calculated using equation (11) with CRF 0.0657. The result for both simple and net present value method as shown in Table VII indicated that the project is profitable except for cost of per kWh criteria for social tariff. The cost of PV energy per kWh higher than PLN tariff social IDR 735 per $\mathrm{kWh}$. This value indicate that the project is not profitable. Therefore, the installation of on grid PV system for university building need to considered the recent electrical tariff regulation.

Table VII. Estimate of PV system economic indicators

\begin{tabular}{l|c|c}
\hline \multicolumn{3}{c}{ Simple Method } \\
\hline \multicolumn{2}{c}{ MV Tariff } & Social Tariff \\
\hline Payback period & 10 & 15 \\
Cost of energy & 687.63 & 687.63 \\
\hline \multicolumn{2}{c}{ Net Present Value Method } \\
\hline Payback period (year/month) & 13 & 20 \\
Cost of energy (IDR/kWh) & 896.58 & 896.58 \\
NPV & $422,672,493$ & $103,832,562$ \\
\hline
\end{tabular}

The potential of PV system energy which can be generated in one year around $32.65 \mathrm{MWh}$ results. Concerning to reduce the global warming, the total amount of $\mathrm{CO}_{2}$ at the atmosphere must be minimized. By using an emissions factor of carbon dioxide gas $0.730 \mathrm{~kg} \mathrm{CO} / / \mathrm{kWh}$ [14], amount of $\mathrm{CO}_{2}$ emission that can be reduced as:

$\mathrm{CO}_{2}$ emissions reduction $=32,650 \mathrm{kWh} \times 0.730 \mathrm{~kg} \mathrm{CO} / \mathrm{kWh}=23,840 \mathrm{~kg}$ or 23.84 Tons

The result shown that by install $26 \mathrm{kWp}$ PV system on the roof of Electrical Engineering building of Universitas Andalas can be expected to reduce 23.84 tons of $\mathrm{CO}_{2}$ per year.

\section{CONCLUSION}

The design of grid connected photovoltaic on the roof of the Electrical Engineering Department building to reduce electrical peak load have been simulated. The Electrical Engineering Department have consumed total daily load demand is $415.1 \mathrm{kWh} /$ day with peak load of $29.5 \mathrm{~kW}$. The design result shows that the peak load of Electrical Engineering Department can be reduced from $29.5 \mathrm{~kW}$ to be $15.9 \mathrm{~kW}$ by install $26 \mathrm{kWp}$ PV system which amounts of PV panels 104 units. The total area needed for PV installation will be $170.23 \mathrm{~m}^{2}$. The initial investment required to build $26 \mathrm{kWp}$ PV system amounts is IDR 445 million. The result of economic analysis shows that NPV positive score, and payback period less than PV system lifespan. The simple payback period is 10 years for MV tariff and 15 years for social tariff. The discounted payback period for MV tariff 13 years and for social tariff 20 years. However, the cost of PV energy per kWh higher than PLN tariff social IDR 735 per $\mathrm{kWh}$. This value indicate that the project is not profitable. Therefore, the installation of on grid PV system for Electrical Engineering Department is feasible for MV tariff used and not for social tariff. Therefore, the installation of on grid PV system for university building need to considered the recent electrical tariff regulation.

\section{ACKNOWLEDGMENT}

The author gratefully acknowledge the assistance rendered by Directorate General of Higher Education Ministry of Research, Technology, and Higher Education for research funding under PTP research grant (Contract No. 050/SP2H/LT/DRPM/2018).

\section{REFERENCES}

[1] Tarigan E, Djuwari and Purba L, Assessment of PV power generation for household in Surabaya using solar GIS-pvplanner simulation, Energy Procedia 47, 2014, pp 85-93

[2] Rencana Strategis Kementrian Energi dan Sumber Daya Mineral (Renstra KESDM) Republik Indonesia, 2015 (http://prokum.esdm.go.id/renstra\%202015)

[3] Hagerman, S., Jaramillo, P. \& M Granger Morgan, 2016. Is rooftop solar PV at socket parity without subsidier?, Energy Policy, 89, pp.84-94.

[4] Mohammad I. Al-Najideen, Saad S. Alrwashdeh, Design of a solar photovoltaic system to cover the electricity demand for the faculty of Engineering- Mu'tah University in Jordan, Resource-Efficient Technologies, 3(4), 2017, pp. 440-445.

[5] IAD. Giriantari, Rina Irawati, Smart Microgrid System with Hybrid System Supply: Udayana University Pilot Project Design, ICSGTEIS Proceeding, 6-8 Oct 2016, Bali.

[6] J.Lee, B. Chang, C. Aktas, R. Gorthala, Economic feasibility of campus-wide photovoltaic systems in New England, Renewable Energy, Vol. 99, 2016, pp. 452-464 
[7] Syafii, Refdinal Nazir, Performance and Energy Saving Analysis of Grid Connected Photovoltaic in West Sumatera, International Journal of Power Electronics and Drive System (IJPEDS), Vol. 7, No. 4, December 2016, pp. 1348 1354.

[8] NASA Surface Meteorolgy and Solar Energy Data, Monthly Averaged Insolation Incident On A Horizontal Surfaces, [Online], available: www.data.nasa.gov/surface-meteorolgy-and-solar energy.

[9] Johann Hernandez, Nelson L. Diaz, and Gerardo Gordillo. Design Dimensioning Model For Grid-Connected Photovoltaic IEEE Int Conf on Systems. Electrical Power \& Energy Conference (EPEC), Univ. Distrital F.J.C., Bogota, Colombia, Oct. 2009.

[10] J Tze San Ong dan Chun Hau Thum, "Net Present Value and Payback Period for Building Integrated Photovoltaic Projects in Malaysia,” International Journal of Academic Research in Business and Social Sciences, Februari 2013.

[11] S.G., Ramadhan and Ch. Rangkuti, Perencanaan Pembangkit Listrik Tenaga Surya Di Atap Gedung Harry Hartanto Universitas Trisakti, Seminar Nasional Cendekiawan 2016.

[12] Viriya P. Singgih (The Jakarta Post), Government maintains energy prices for Q1 2018 [online], available: http://www.thejakartapost.com/news/2017/12/27/government-maintains-energy-prices-for-q1-2018.html

[13] Bank Indonesia Republik Indonesia 2018 [online], available: http://www.bi.go.id/id/Default.aspx

[14] Moien A.Omar, Marwan M.Mahmoud, Grid connected PV- home systems in Palestine: A review on technical performance, effects and economic feasibility, Renewable and Sustainable Energy Reviews, Volume 82, Part 3, February 2018, Pages

\section{AUTHOR PROFILE}

Syafii received B.Sc degree in electrical engineering from University of North Sumatera in 1997, and M.T. degree in electrical engineering from Bandung Institute of Technology, Indonesia, in 2002 and Ph.D degree from Universiti Teknologi Malaysia in 2011. He is currently a senior lecture in Dept. of Electrical Engineering, Universitas Andalas, Indonesia. His research interests are new and renewable energy, smart grid and power system computation.

Zaini received B.Sc degree in electrical engineering from Universitas Andalas in 1999, and M.Sc. degree in electrical engineering from UMIST, Manchester, UK, in 2002 and Ph.D degree from University of Bradford in 2013. He is currently a senior lecture in Dept. of Electrical Engineering, Universitas Andalas, Indonesia. His research interests are renewable energy, and electric power train.

Dona Juliandri received B.Sc degree in electrical engineering from Universitas Andalas in 2011. He is currently a magister student in Dept. of Electrical Engineering, Universitas Andalas, Indonesia. His research interests are new and renewable energy, and power system operation and control.

Wati received B.Sc degree in accounting education from Padang State University, and Master Degree in economic education from Padang State University, in 2014. She is currently a lecture in Accounting Education Department, STKIP PGRI Sumatera Barat, Indonesia. Her research interests are scavengers community and environment, economic analysis and entrepreneurship. 